\title{
Postprandial angina: not always due to stenotic coronary artery disease
}

\author{
Gopal Chandra Ghosh, John Jose, Paul V George
}

\begin{abstract}
- Additional material is published online only. To view please visit the journal online (http://dx.doi.org/10.1136/ bcr-2017-223030).
\end{abstract}

Department of Cardiology, Christian Medical College and Hospital, Vellore, Tamil Nadu, India

Correspondence to Dr Gopal Chandra Ghosh, gcghosh86@gmail.com

Accepted 17 October 2017
To cite: Ghosh GC, Jose J, George PV. BMJ Case Rep Published Online First: [please include Day Month Year]. doi:10.1136/bcr-2017223030

\section{DESCRIPTION}

A 68-year-old man presented with history of postprandial angina for 6 months. He was a diabetic and hypertensive for 10 years. He was also a reformed smoker with 20 pack-years history of smoking. He did not give any history of acute coronary syndrome or any cardiac catheterisation. Clinical examination was unremarkable. ECG and chest X-ray were normal. Echocardiography revealed normal left ventricular function with features of left ventricular hypertrophy.

Coronary angiography revealed abnormal spillage of contrast in the left ventricular apical region with each diastole from obtuse marginal (OM) branch of left circumflex coronary artery (LCx) and distal part of left anterior descending coronary artery (LAD) suggestive of coronary-cameral fistula (CCMF) (figure 1, figure 2, online supplementary video 1). Coronary angiography did not show any signs of atherosclerotic coronary artery disease. Absence of dilated communicative fistulous tracts between the coronary arteries and the drainage chamber was suggestive of arteriosinusoidal type of CCMF (online supplementary videos 2 and 3). Patient was managed conservatively.

CCMF is a communication between any of the coronary arteries and any of the cardiac chambers or major vessels like pulmonary artery and coronary sinus. CCMF is a very rare cardiac anomaly, commonly congenital in origin but can also develop as a complication of cardiac trauma during cardiac catheterisation. Most of the CCMF are incidentally

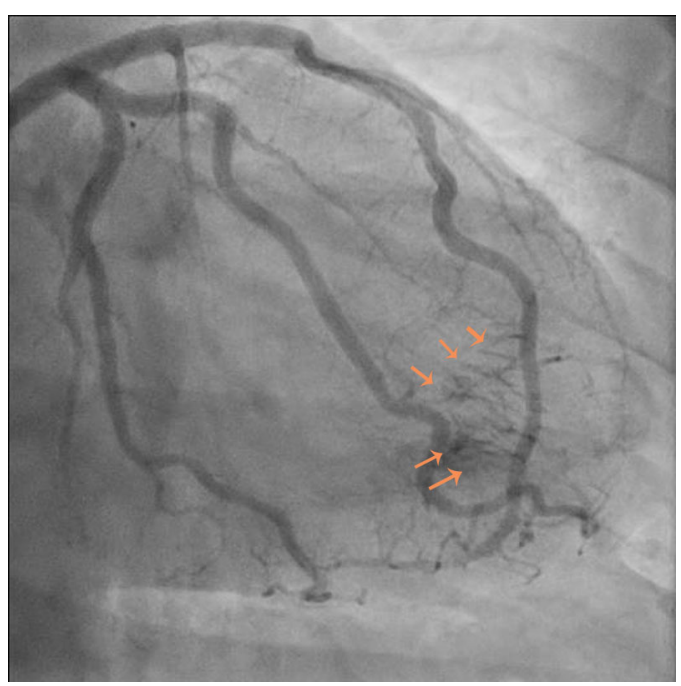

Figure 1 Selective left coronary angiogram, right anterior oblique caudal view showing spillage of contrast (orange arrows) into the left ventricular apical region.

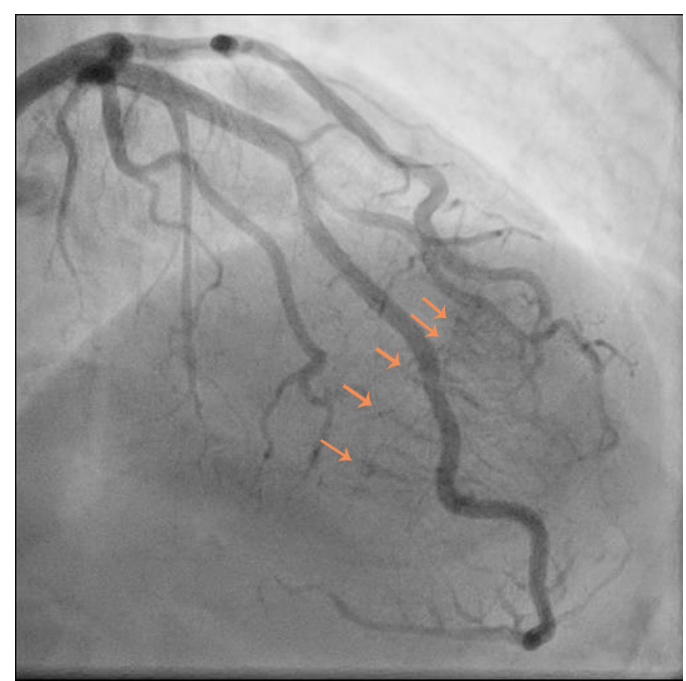

Figure 2 Selective left coronary angiogram, right anterior oblique cranial view showing spillage of contrast (orange arrows) into the left ventricular apical region.

detected during coronary angiography. Vavuranakis et al have reported an incidence of $0.1 \%$ in the unselected patients undergoing diagnostic coronary angiography. ${ }^{1} \mathrm{CCMF}$ originates from the right coronary artery (55\%), left coronary artery (35\%) and both coronary arteries (5\%) and commonly drains into the right ventricle (40\%), right atrium (26\%) and pulmonary arteries (17\%). Drainage into the superior vena cava and coronary sinus is rare, and into the left atrium and left ventricle is hardly reported in the literature. ${ }^{2}$

Mostly CCMF are asymptomatic and the development of symptoms depends on the size of the fistula, site of origin and drainage of the communication tracts. Anginal symptoms are due to coronary steal phenomenon or diastolic overload of the drainage chamber. Other rare complications of Coronary-cameral fistula (CCMF) are thrombosis and embolism, cardiac failure, atrial fibrillation, rupture, endocarditis/endarteritis and arrhythmias. $^{3}$

Based on the types of the communication, CCMF can be divided into (1) arterioluminal (direct communication with cardiac chambers) and (2) arteriosinusoidal (communication via sinusoidal network into a chamber without a direct communication) subtypes. This differentiation is helpful in determining the management plan. Symptomatic arterioluminal subtype can be successfully closed by surgery or device, whereas arteriosinusoidal subtype is less amenable to surgery and beta blockers can be tried as an alternative. ${ }^{3}$ 
Our case was unique in the following aspects. First, presentation at the age of 68 years is a rare occurrence for a congenital-origin lesion. Second, origin of the coronary-cameral fistula from the OM branch of LCx and distal LAD and draining into the left ventricular cavity are very rare. Our patient had an arteriosinusoidal type of CCMF so he was initiated on beta-blocker therapy.

\section{Learning points}

- Coronary-cameral fistula, although a rare entity, is an important cause for angina.

- It originates from the right coronary artery or left anterior descending coronary artery or both coronaries and drains mostly into the right side of heart.

- Origin from the obtuse marginal branch of left circumflex artery and left anterior descending artery and draining into the left ventricle are very rare.
Contributors GCG is the primary author and performed writing, editing and literature search. JJ helped in editing and case discussion. PVG is the senior author, was involved in editing and supervising the manuscript.

Competing interests None declared.

Patient consent Obtained.

Provenance and peer review Not commissioned; externally peer reviewed.

(c) BMJ Publishing Group Ltd (unless otherwise stated in the text of the article) 2017. All rights reserved. No commercial use is permitted unless otherwise expressly granted.

\section{REFERENCES}

1 Vavuranakis M, Bush CA, Boudoulas H. Coronary artery fistulas in adults: incidence, angiographic characteristics, natural history. Cathet Cardiovasc Diagn 1995:35:116-20.

$2 \mathrm{Ho} \mathrm{HH}$, Cheung CW, Jim MH, et al. Coronary-cameral fistula. Heart 2005;91:1540.

3 Nagpal P, Khandelwal A, Saboo SS, et al. Symptomatic coronary cameral fistula. Heart Views 2015;16:65-7.

Copyright 2017 BMJ Publishing Group. All rights reserved. For permission to reuse any of this content visit http://group.bmj.com/group/rights-licensing/permissions.

BMJ Case Report Fellows may re-use this article for personal use and teaching without any further permission.

Become a Fellow of BMJ Case Reports today and you can:

- Submit as many cases as you like

- Enjoy fast sympathetic peer review and rapid publication of accepted articles

- Access all the published articles

- Re-use any of the published material for personal use and teaching without further permission

For information on Institutional Fellowships contact consortiasales@bmjgroup.com

Visit casereports.bmj.com for more articles like this and to become a Fellow 